are of importance in connexion with the effect of gusts on wing-load. The angle of incidence of the aerofoil under test is rapidly altered by a spring mechanism; the resulting change of lift on the aerofoil is recorded piezo-electrically.

Much work is being done in the Department on turbulent airflow. Extensive use is being made of shadowgraph methods in which the motion of spots of hot air produced by electric sparks is observed photographically. Apparatus has been devised for obtaining cinematograph records of the air flow, and in this work the Schlieren method of photography has proved of assistance.

The equipment of the Department has been augmented by the construction of a high-speed wind tunnel operated from the exhaust of the compressed. air tunnel. This tunnel, which is one foot in diameter, is expected to give wind speeds in the neighbourhood of $950 \mathrm{ft}$. per second. The tunnel is to be used for the study of the behaviour of aerofoils at high wind speeds, with particular reference to the aerodynamic efficiency of the tip sections of airscrews at high speeds.
The William Froude Laboratory is engaged on extensive research on the mancouvring of ships. The work has shown that in certain cases, the performance of a rudder can be considerably improved by an alteration in propeller design. The effects of introducing a fin in front of the rudder are being investigated in the case of single-screw ships. A model of a single-screw vessel equipped with apparatus for measuring steering qualities was exhibited.

For research on propeller efficiency, a $24 \mathrm{ft}$. wooden model of a single-screw cargo ship has been constructed, complete with self-propelling gear and automatic recording apparatus for measuring the thrust capacity of propellers. The model is available for testing propellers of any design. A closed circuit tunnel for research on model propellers-the gift of Sir James Lithgow-has been added to the Department. The new tunnel will facilitate the study of the action of propeller blades, with particular reference to the cause of erosion. Stroboscopic methods are provided for observing the propeller while it is in motion.

\title{
Jubilee of the Junior Institution of Engineers
}

$\mathrm{T}$ HE Junior Institution of Engineers celebrated its jubilee on June 27-29. The Institution was founded in 1884 by a group of young engineers employed at the works of Messrs. Maudslay, Sons and Field of Lambeth, and it has always fostered "the Junior spirit". Open to men of all ages engaged in any branch of engineering and allied professions, it demands no examination of its members, and its meetings and discussions are marked by an absence of formality. Its first president was Mr. Freke Field, a grandson of Joshua Field (1787-1863), the partner of Henry Maudslay, who himself in 1818 was the first chairman of the newly founded Institution of Civil Engineers, and its president in 1848. The successors of Mr. Freke Field have included the late Sir Alexander Kennedy, John Perry, Silvanus Thompson, Sir William White, Lord Moulton, Sir Dugald Clerk, and many other distinguished men still living, eleven of whom were present at the luncheon at the Hotel Victoria on June 27 with which the jubilee proceedings were inaugurated, and at which Mr. W. J. Tennant, the present president, presided.

The luncheon on Wednesday was followed by a special service in St. Paul's Cathedral attended by the Institution as "an act of thanksgiving for 50 years of steady progress and attainment" ; a reception at the Mansion House by the Lord Mayor and Lady Mayoress, and a conversazione at the Science Museum, South Kensington. A special exhibition of models, tools and drawings relating to the Lambeth firm, and to men who had been associated with it, had been arranged, and during the course of the evening an illustrated lecture on Maudslay, Sons and Field and the Royal Navy, was given by Eng.-Capt. Edgar C. Smith. After a brief reference to the formation of the institution and the world's great debt to young inventors and engineers, of which there were many notable illustrations in the Museum, Capt. Smith said that the history of the firm of Maudslay is of interest for many reasons; first, because of the many eminent engineers who built up its fortunes and maintained its traditions ; secondly, on account of its work as a training school for mechanical engineers; thirdly, because it recalls a time when marine engineering was a flourishing industry on the Thames, carried on not only by Maudslays but also by Penn, Humphry, Miller, Ravenhill, Rennie, Seaward and others ; and lastly, as the firm which during the nineteenth century supplied more marine machinery to the Royal Navy than any other.

The first vessel engined for the Navy by Maudslays was H.M.S. Lightning, 1823, and she was succeeded by such notable vessels as the Rhadamanthus, the first steam man-of-war to cross the Atlantic, the Terrible, the largest paddle wheel frigate, the Rattler, the first steam screw-driven man-of-war, the Marlborough, the Iris and Mercury, the Blake and many others. In all the various changes and advances in marine propulsion, Maudslays played a great part, and the last engines constructed by them represented the highest pitch of mechanical engineering during the nineteenth century.

The events of Thursday included a visit to the Cricklewood works of Smith's English Clocks Ltd., and the delivery by Sir Frank Smith, secretary of the Department of Scientific and Industrial Research, of the Gustave Canet Memorial Lecture of the Institution at the Royal Society of Arts. This lecture was founded by Madame Canet, the widow of Gustave Canet (1846-1908), the distinguished French ordnance engineer who died while he was holding office as president of the Institution.

Sir Frank Smith took as his subject "The Engineer and Modern Civilisation". The structural engineer of early times, he said, carrying out great works without a knowledge of science, either consciously or subconsciously followed the principles which Nature pursues in creating our own struetures. The engineer of to-day is distinguished from his predecessor inasmuch as he studies structures of microscopic size as well as those of gigantic proportions, and in this way is able to improve his materials and discover new ones. Modern civilisation, he continued, is a blend of two cultures : the engineering culture embracing the sciences, industry and commerce, and an idealistic culture including the fine arts and philosophy. What distinguishes so markedly our modern ciyilisation from that of a hundred or even fifty years ago is that 
the materialistic culture is much more advanced than ever before.

The composite work which makes up our civilisation looks quite different when seen through the spectacles of an electrical, civil or mechanical engineer. The first would point to the vast output of electrical machinery and appliances, the second to the great railways, bridges and dams, and the last to inventions which made possible the developments of tools and machines. It was Maudslay's slide-rest lathe and Whitworth's accurate straight-edges and surfaceplates which made it possible to construct the modern internal combustion engine.

There is also a picture of labour displaced by machinery; sweeping economies in labour being made in factories, mills and offices. With mechanical equipments on farms, 1,000 acres can be ploughed, prepared and sown in a single day, and ten minutes of human labour suffices to produce a bushel of wheat whereas formerly three hours were required. The pleasant picture of the English country-side a century ago with its hay wains and reapers was accompanied by another of Iong hours and child labour in factories. The engineer by his inventions has made child labour unnecessary and farm work less exacting; many who pine for 'the good old days' labour under deceptions similar to those which often mislead travellers in tropical countries-they see mirages of oases in plenty in the rear while the real oases lie right ahead. Stuart, more than a century ago, estimated that the steam engines in use in Great Britain developed more power than 4,500,000 labourers; to-day, steam turbines develop more power than 450 millions of Stuart's labourers, while in the United States it is estimated that every individual has an average of 900 such 'slaves'. The engineer, too, has banished the fear of famine; he has supplied fertilisers for the soil, agricultural machinery of wonderful efficiency, transport facilities of remarkable speed, and cool controlled atmospheres for keeping food fresh and palatable over long periods. At the conclusion of his lecture, Sir Frank Smith was presented with the Gustave Canet Gold Medal.

\section{University and Educational Intelligence}

BIRMINGHAM.-On June 30 the honorary degree of LL.D. was conferred on the following, among others: The Right Hon. the Earl of Derby, Chancellor of the University of Liverpool; Sir John Cadman, emeritus professor of mining in the University, chairman of the Anglo-Persian Oil Company; Sir Harry McGowan, president and chairman of Imperial Chemical Industries, Ltd.; Dr. G. T. Morgan, director of the Chemical Research Laboratory, Teddington; Prof. C. A. Lovatt Evans, Jodrell professor of physiology, University College, London.

THE following appointments have been made: Philip Cloake, joint professor of medicine, to succeed Prof. J. G. Emanuel who has resigned; J. M. L. Burtenshaw, lecturer in bacteriology; T. G. Hunter, assistant lecturer in oil engineering.

CAMbridge.-In the annual report of the Committee of Management of the Scott Polar Research Institute it is stated that the formal opening of the new buildings will take place in the autumn, probably on November 16, when the Chancellor of the
University (Mr. Stanley Baldwin) has consented to perform the opening ceremony.

The Harkness Scholarship, valued at $£ 150$, awarded for proficiency in geology, has been won by J. K. S. St. Joseph, Bromsgrove and Selwyn. The Wiltshire Prize for geology and mineralogy in connexion with Part I of the Natural Sciences Tripos has been awarded to S. O. Agrell, Bedales and Trinity Hall.

The Frank Smart Prizes have been awarded to G. C. Evans, St. John's (botany), who was placed in Class I in Part 2 of the Natural Sciences Tripos and A. L. Hodgkin, Trinity (zoology and comparative anatorny), who was placed in Class I in Part 1 of the same tripos.

At Magdalene College D. Purdie Kings has been elected to the Charles Kingsley bye-fellowship.

At St. John's College the following have been elected into fellowships:-Dr. M. L. O. Oliphant, of Trinity College, Messel research fellow of the Royal Society, and O. A. Trowell, formerly scholar of St. John's College, University demonstrator in physiology.

Durham.--At the June Convocation held on June 27, the honorary degree of D.Sc. was conferred on Prof. A. Fowler, professor of astrophysics in the University of London.

Edinburgh.-On June 28 the honorary degree of LL.D. was conferred on the following, among others: Dr. Robert Hutchison, physician to the London Hospital; Prof. Robert Robinson, Waynflete professor of chemistry in the University of Oxford; Dr. Theobald Smith, emeritus director of the Department of Plant Pathology, Princeton, New Jersey, former director of the Rockefeller Institute; Sir John Maxwell Stirling-Maxwell, formerly chairman of the Forestry Commission and chairman of the Ancient Monuments Board (Scotland) ; Prof. D'Arcy Wentworth Thompson, professor of natural history in the University of St. Andrews.

The degree of D.Sc. was conferred on the following for the theses indicated: G. H. Bates ("SemiNatural Vegetation and the Biotic Factor"); Charles Ockrent ("Studies in Active Charcoal"); C. M. Scott ("The Sensitivity of Cells to the Lethal Action of X-Rays"); George Taylor ("An Account of the Genus Meconopsis") ; Dr. S. A. Kinnier Wilson ("The Experimental and Applied Physiology of the Corpus Striatum").

London.- The Kent County Council has decided to make a grant of $£ 40,000$, payable over ten years, towards the cost of erecting new University buildings on the Bloomsbury site, and the Worshipful Company of Butchers has made a grant towards the Ceremonial Hall.

St. Andrews.-On June 29, the honorary degree of LL.D. was conferred on the following, among others: Lord Moynihan, emeritus professor of surgery in the University of Leeds; and Sir Frederick Gowland Hopkins, president of the Royal Society.

Mr. Ivor Griffiths and Mr. P. Jacobs have been awarded Streatfeild scholarships under the Royal College of Physicians and the Royal College of Surgeons to carry out an investigation into the tonsil, its anatomy, physiology, and the relations of its lymphatic vessels. 